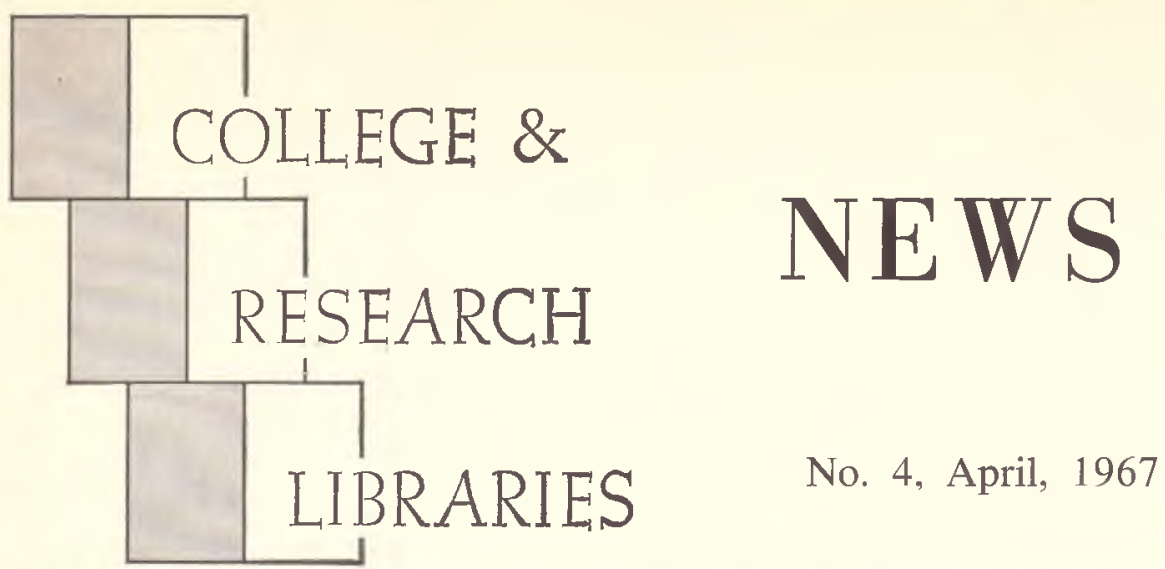

ACRL News Issue (B) of College \& Research Libraries, Vol. 28, No. 2

\title{
Schedule of Meetings
}

\section{Annual Conference}

San Franctsco, California

JUNE 25-JuLY 1, 1967

The following schedules are tentative. Meetings will be held in Brooks Hall and at several hotels; a final schedule, with location, will be mailed by Mary Cilluffo, assistant for conference arrangements, to officers and chairmen of ALA groups. Each chairman should notify members of his activity.

Program meetings. For details, refer to the ALA Bulletin for May 1967.

ACRL Membership meEting

Thursday, June 29, 2:00-4:00 p.m.

\section{ACRL/RTSD}

Thursday, June 29, 8:30-10:00 p.m.

College Libraries Section

Friday, June 30, 2:00-6:00 p.m.

\section{Junior College Libraries Section}

Wednesday-Saturday, June 21-24, Preconference, University of California, Los Angeles

Tuesday, June 27, 1:00-6:00 p.m. Tour

Friday, June 30, 12:00-4:00 p.m. Luncheon

\section{Rare Books Section}

Thursday-Saturday, June 22-24, Preconference, Stanford University
Subject Specialists Section and

Agriculture and Biological

Sciences Subsection

Wednesday, June 28, 4:30-6:00 p.m.

\section{Art Subsection}

Friday, June 30, 12:30-4:00 p.m. Luncheon and Tour

Saturday, July 1, 9:30 a.m.-2:00 p.m. Tour and Luncheon

Law and Political Science Subsection Thursday, June 29, 8:30-9:30 a.m.

University Libraries SEction

Wednesday, June 28, 8:30-10:00 p.m.

\section{Business Meetings}

ACRL Board of Directors

Thursday, June 29, 8:30-10:00 p.m.

Friday, June 30, 2:00-4:00 p.m.

\section{ACRL COMMITTEes}

\section{Audio-Visual Committee}

Tuesday, June 27, 4:30-6:00 p.m.

Tuesday, June 27, 8:30-10:00 p.m.

\section{Committee on Community Use of} Academic Libraries

Monday, June 26, 10:00 a.m.-12 noon

Tuesday, June 27, 8:30-10:00 p.m. 
Advisory Committee on Cooperation with Educational and Professional

Organizations

Monday, June 26, 12:15-2:00 p.m.

Luncheon

\section{Committee on Grants}

Monday, June 26, 8:00-9:30 a.m. Breakfast

Committee on Liaison with

Accrediting Agencies

Wednesday, June 28, 12:30-2:00 p.m. Luncheon

Committee on Library Services

Thursday, June 29, 8:30-9:30 a.m.

Friday, June 30, 4:30-6:00 p.m.

Committee on Library Surveys

To be scheduled

National Library Week Committee

Not yet scheduled

Planning and Action Committee

Tuesday, June 27, 2:00-4:00 p.m.

Friday, June 30, 7:00-8:30 a.m. Breakfast

INDEXERS NEEDED: THE H. W. WILSON COMPANY has immediate openings for indexers in the following periodical and book indexes-APPLIED SCIENCE \& TECHNOLOGY INDEX, BOOK REVIEW DIGEST, BUSINESS PERIODICALS INDEX, CUMULATIVE BOOK INDEX, EDUCATION INDEX, LIBRARY LITERATURE, and STANDARD CATALOG.

Applicants for the periodical indexes should be able to assign subject headings to articles in current journals. It is desirable that applicants for BOOK REVIEW DIGEST, CUMULATIVE BOOK INDEX and STANDARD CATALOG have cataloging experience. Applicants for APPLIED SCIENCE \& TECHNOLOGY INDEX, BUSINESS PERIODICALS INDEX and EDUCATION INDEX should have some subject background. Salary will depend on qualifications and experience and will be reviewed annually. Many Company benefits such as vacations, sick pay, pensions, Blue Cross, Blue Shield, Major Medical, etc. 5 day, 35 hour week.

Applications should be addressed to:

The Personnel Department

The H. W. Wilson Company

950 University Avenue

Bronx, New York 10452
Publications Committee

Thursday, June 29, 8:00-9:30 a.m.

Ad Hoc Committee on Relations with ARL Not yet scheduled

\section{Committee on Standards}

Monday, June 26, 4:30-6:00 p.m.

Tuesday, June 27, 4:30-6:00 p.m.

Wednesday, June 28, 8:30-10:00 p.m.

\section{Joint CommitTeEs}

AAJC/ALA(ACRL) Committee on

Junior College Libraries

Sunday, June 25, 10:00 a.m.-4:00 p.m. Luncheon

ACRL Publications, Editorial Boards

CHOICE

Sunday, June 25, 10:00 a.m.-12 noon

College \& Research Libraries

Wednesday, June 28, 4:30-6:00 p.m.

Monograph Series

Tuesday, June 27, 12:00-2:00 p.m. Luncheon

ACRL Sections and Subsections

College Libraries Section

Wednesday, June 28, 4:30-6:00 p.m.

Committee on Non-Western Resources Thursday, June 29, 8:30-10:00 p.m.

Junior College Libraries Section

Monday, June 26, 8:30-10:00 p.m.

Committee on Instruction and Use Thursday, June 29, 8:30-9:30 a.m.

Instructional Materials Center Committee (Ad-Hoc)

Wednesday, June 28, 4:30-6:00 p.m.

Committee on Vocational Education (Ad-Hoc)

Thursday, June 29, 8:30-10:00 p.m.

Subject Specialists Section

Thursday, June 29, 4:30-6:00 p.m.

SS Slavic and East European Subsection Wednesday, June 28, 4:30-6:00 p.m.

University Libraries Section

Wednesday, June 28, 4:30-6:00 p.m.

Academic Status Committee (Ad-Hoc)

Sunday, June 25, 2:00-4:00 p.m.

Committee on Extension Library Service Thursday, June 29, 8:30-9:30 a.m. 


\section{Q. Who is Taylor-Carlisle?}

A. Taylor-Carlisle has been bookseller to libraries in the academic and scientific communities for over 20 years.

Q. What is Taylor-Carlisle?

A. Taylor-Carlisle is an organization designed for service -the fast, efficient service such libraries must have.

Q. How does Taylor-Carlisle operate?

A. Taylor-Carlisle, with its experienced personnel, tremendous inventory, and proximity to major publishers, is equipped to fill your orders quickly and efficiently.

Q. How about prices? Discounts?

A. Our terms are particularly advantageous to libraries in the academic world. Write to us for complete details.

Please address: Mr. A. Fagan

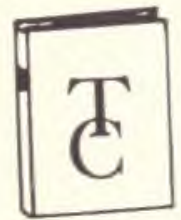

Taylor-Carlisle Books

115 East 23rd Street

New York, N.Y. 10010

Tel.: (212) 674-7788 